\title{
Environment as Cultural Heritage: The Armenian Diaspora's Willingness to Pay to Protect Armenia's Lake Sevan
}

\author{
By \\ Benoit Laplante \\ Independent Consultant, Montreal, Canada \\ Craig Meisner \\ and \\ Hua Wang \\ Development Research Group \\ World Bank
}

World Bank Policy Research Working Paper 3520, February 2005

The Policy Research Working Paper Series disseminates the findings of work in progress to encourage the exchange of ideas about development issues. An objective of the series is to get the findings out quickly, even if the presentations are less than fully polished. The papers carry the names of the authors and should be cited accordingly. The findings, interpretations, and conclusions expressed in this paper are entirely those of the authors. They do not necessarily represent the view of the World Bank, its Executive Directors, or the countries they represent. Policy Research Working Papers are available online at http://econ.worldbank.org.

Corresponding address:

Hua Wang

MC2525, World Bank

1818 H Street, NW

Washington, DC 20433

USA

hwang1@worldbank.org. 


\begin{abstract}
This paper presents a study of willingness-to-pay of the Armenian Diaspora in the United States to protect Armenia's Lake Sevan, a unique and precious symbol of the Armenian cultural heritage. Dichotomous choice contingent valuation questions were asked by mail surveys to elicit respondents' willingness to pay for the protection of Lake Sevan. The results show that on average, each household of the Armenian Diaspora in the United States would be willing to provide a one-time donation of approximately US\$80 to prevent a further degradation of Lake Sevan, and approximately US\$280 to restore the quality of the lake by increasing its water level by 3 meters.
\end{abstract}

Key words - Willingness-to-pay, Donation, Diaspora, Armenia 


\section{Introduction}

Lake Sevan is the largest high altitude reservoir of freshwater in the Transcaucasus, and is one of the highest lakes in the world. However, over the course of 50 years, the level of the lake has dropped by 18 meters, its surface area has decreased by $15 \%$, and the volume of water in Lake Sevan fell by more than $40 \%$ (from 58.5 to 34.6 $\mathrm{km}^{3}$ ). These changes had various significant adverse impacts on Lake Sevan's ecology. Perhaps as or more importantly, Lake Sevan is a very major component of Armenia's cultural heritage, along with its religion and churches. Indeed, it is often said that Lake Sevan defines the people of Armenia.

The Government of Armenia has been working on a Lake Sevan protection action plan. The objectives under consideration by the Government of Armenia include preventing a further lowering of the level of Lake Sevan, and raising the level of the lake by at least 3 meters as quickly as possible. Cost-benefit analyses to this date have demonstrated a large negative net present value for all projects and options aimed at achieving this objective, ranging from 72 to 147 million dollars. However, the estimation of the benefits with this protection plan is to this day incomplete. In particular, the estimation of the recreational and non-use values of Lake Sevan has not been addressed.

As a result of various historical events, there is a very large Armenian Diaspora, living mainly in the United States, France, Syria, Iran, Lebanon, and New Independent States (NIS) countries. The greater Los Angeles area alone accounts for approximately 800,000 Armenians. Armenians living abroad currently donate large sums of money and goods to various Armenian funds, and transfer money directly to relatives in Armenia. In the 1990s, these donations have been estimated to even be larger than the size of the total state budget. Furthermore, in various forums, the Armenians of the Diaspora have expressed strong interest in the protection of Lake Sevan and restoration of its quality. 
This paper presents a study of willingness to pay (WTP) for Lake Sevan restoration projects by those Armenians of the Diaspora living in the United States. Surveys have been conducted in the United States to assess the magnitude of the willingness to donate for Lake Sevan protection.

Armenia is not alone with a large Diaspora living outside its boundaries. Indeed, a large number of developing countries share a similar characteristic (e.g. North Africans in Europe). This Diaspora may truly value public commodities such as unique environmental resources in their original country and may express a willingness to invest in the protection of these resources. To our knowledge, this paper is unique in two different ways. First, in the literature on the economics of cultural heritage, it appears this is the first willingness-to-pay study in which a natural asset (such as a lake) constitutes the cultural site of interest. Second, it would also appear to be the first time that a Diaspora constitutes the targeted population.

The paper is structured as follows. In Section II, we begin by describing Lake Sevan, its preservation challenges, and its cultural significance among the Diaspora. In Section III, we describe the process of data collection along with some descriptive statistics of interest. In section IV, willingness-to-pay models are developed and estimated under alternative management scenarios. We conclude briefly in Section V.

\section{Lake Sevan and the Armenian Diaspora \\ II.1 Lake Sevan}

The Republic of Armenia has a total area of approximately $29,740 \mathrm{~km}^{2}$ making it the smallest of the former republics of the Soviet Union. The country is dominantly mountainous with $72 \%$ of land above 1,500 meters.

Located to the northeast of the capital city Yerevan, Lake Sevan is the largest high altitude reservoir of fresh water in the Transcaucasus, and is one of the largest alpine 
lakes in the world with a total surface area of $1,248 \mathrm{~km}^{2}$ at $1,916 \mathrm{~m}$ above sea level. Its present length along the main axis is $74 \mathrm{~km}$; the average and maximum widths are $19 \mathrm{~km}$ and $32 \mathrm{~km}$ respectively. Its watershed covers an area of $4,851 \mathrm{~km}^{2}$, about one-sixth of the country's area. Twenty eight rivers flow into Lake Sevan. The Hrazdan River, the only outlet from the lake, flows into the Ararat Valley where the capital city Yerevan is located, and where most of Armenia's agricultural production is taking place. In its course to the valley, the Hrazdan River drops over 1,000 m.

In the late 1920s, Soviet engineers started to examine the potential for a more intensive utilization of Lake Sevan water as a source of hydroelectric power, and irrigation in the Ararat Valley. In 1930, a plan was thus developed to increase water discharge into the Hrazdan River from $50 \mathrm{Mm}^{3}$ a year to approximately $700 \mathrm{Mm}^{3}$. Water withdrawals peaked over the period 1949-1962. The impact of such water withdrawal on the ecology of Lake Sevan was severe: Over the course of only 50 years, the level of the lake dropped by $18 \mathrm{~m}$; its surface area decreased from 1,416 to $1,239 \mathrm{~km}^{2}$; and the volume of water in Lake Sevan fell by more than $40 \%$ (from 58.5 to $34.6 \mathrm{~km}^{3}$ ).

The lowering of the level of water in Lake Sevan caused several important perturbations to the ecology of the lake with severe implications, including the loss of breeding grounds for a number of fish species believed to be endemic to Lake Sevan; a significant reduction of bird diversity due to the drainage of shallow marshes, and a deterioration of the quality of recreational amenities and aesthetic beauty of the lake.

Perhaps of greater importance, Lake Sevan figures prominently in Armenia's culture, history, art, poetry, and music over many centuries. It is regarded by Armenians with esteem and adoration. Erected on an island is the Sevan Monastery founded in 874 a.d. (due to the lowering of the lake, the island has become a peninsula). It is from this monastery that King Ashot Bagratuni defeated the Arab troops thus paving the way to Armenia's independence more than 2,500 years ago. Lake Sevan is thus an integral part 
of Armenia's cultural heritage, and is regarded as a true national treasure, to a large extent defining the people of Armenia.

In response to these concerns, various plans have been considered not only to halt the lowering of Lake Sevan but also to increase its level by up to 3 meters. These plans include: (1) restricting the discharge of water from the lake to $370 \mathrm{Mm}^{3}$ a year; (2) constructing a reservoir (Yeghvard Reservoir) downstream of Lake Sevan to store the water discharged from the lake in winter (to produce electricity), for use in the summer (for irrigation) thus reducing the need to increase water discharges in summer; and (3) diverting an average $165 \mathrm{Mm}^{3}$ of water per year from the upper Vorotan river by completing the Vorotan Diversion Project.

Studies to date have estimated that all of these projects entail a large negative net present value. However, existing estimates of costs and benefits pertaining to preventing a further lowering or to increasing the level of the lake have not accounted for the recreational and non-use values of Lake Sevan. In this regard, existing studies have underestimated the true benefits of protecting Lake Sevan to the Armenian people. Of particular interest in this paper is the non-use (cultural) value that the Armenian Diaspora may attach to Lake Sevan as it may be argued that these values should be incorporated into the analysis for a better understanding of the economic impacts of various actions the government of Armenia may take to protect the Lake.

Cultural heritage, although a topic of much interest to social science for some time, has only recently attracted the attention of economists. A brief examination of recent cultural heritage valuation studies reveals only a decade or so of research. It is of interest to note that most studies have focused on the valuation of historic or archeological sites (see Appendix I and Noonan, 2002). ${ }^{1}$ The scope of these studies is vast, ranging from the restoration or preservation of local sites to the valuation of UNESCO World Heritage Sites. It is of further interest to note that the sampled

\footnotetext{
${ }^{1}$ Other areas of interest also include the arts (performing), broadcast viewing, libraries and sports.
} 
populations in these valuation studies consist almost exclusively of those living in close proximity to the site of interest, or to those visiting the site.

To our knowledge, our study is the first of this nature in which a natural asset (such as a lake) constitutes the cultural site of interest, and in which the sampled population is made of a group physically distant from the site of interest, but have a cultural bond to their nation of origin.

\section{II.2 The Armenian Diaspora ${ }^{2}$}

As a result of numerous historical events (natural and otherwise), Armenians of the Diaspora are currently in larger number than Armenians living in Armenia: of the estimated 7 to 9 million people of Armenian origin worldwide, approximately 3 million currently live in Armenia. Large Armenian communities are currently present in the Middle East (especially Syria and Lebanon), Western Europe (mainly France), and the United States.

By far the largest Armenian community outside of Armenia is found in the United States where approximately 1 million Armenians currently live with well over 100 churches, schools, associations, academic and cultural societies, magazines and newspapers, and influential organizations. A first wave of immigration to the USA took place between 1895 and 1920. The population of Armenians in the USA then increased from approximately 15,000 in 1900 to 70,000 by 1920 . These early immigrants settled mainly in the industrial and urban centers of the east Coast, primarily in New York, Massachusetts, Connecticut and New Jersey, with some settlements in Detroit and Chicago. A second large wave of immigration took place in the 1970s and 1980s when Armenians fled the civil war in Lebanon, the fundamentalist Islamic Revolution in Iran,

\footnotetext{
${ }^{2}$ This section does not pretend to provide a comprehensive description of the Armenian Diaspora. Given the high degree of organization and dynamism of the Diaspora, numerous accounts have been made of the Armenian Diaspora. Among numerous other sources of information, see http://countrystudies.us/armenia/29.htm and http://www.armembassycanada.ca/diaspora/diaspora.htm.
} 
the 1988 earthquake which destroyed thousands of dwellings especially in northern Armenia, and the poor economic conditions which resulted from the break-up of the Soviet Union. This second large wave of immigrants has preferred to locate on the West Coast, mainly in the Los Angeles area, where approximately 800,000 Armenians currently live.

Through the church, charitable organizations (of which the Armenian General Benevolent Union - AGBU - founded in 1905 remains an important component), university professorships (the Armenian Diaspora in the United States has endowed 8 university professorships in Armenian studies), and a network of newspapers, journals, conferences and events, the Armenian Diaspora has maintained its coherence, culture and heritage of which Lake Sevan is an integral and important component. ${ }^{3}$

\section{The Survey \\ III.1 Survey operation}

Considering the project budget and the feasibility of conducting surveys in different countries where the Armenian Diaspora are currently located, the USA was selected to be the survey area. The choice of survey format was also essentially dictated by budget and logistical implications. To this effect, it was deemed that in-person interviews would be too costly to undertake. Telephone interviews were also considered. However, when compared to mail surveys, it was felt that the mail response rate would be more favorable, and thus mail surveys were thus selected as the survey format.

In order to construct a sample of individuals in the United States who are Armenian or who are of Armenian descent, we exploited the unusual property that approximately 99\% of Armenian's last names end in "ian", and the further property that

\footnotetext{
${ }^{3}$ While designing the implementation of this study, discussions were held with numerous representatives of the Armenian Diaspora in the United States. We always received profuse thanks for our effort to "save" Lake Sevan even from individuals of Armenian origin who had never been to Armenia, nor ever seen Lake Sevan except in pictures and paintings.
} 
only Armenian names have this unusual characteristic. ${ }^{4}$ Using this criterion, we performed a search within a CD-ROM national database of US telephone directories in the United States (Powerfinder, 2001). This database contains over 110 million names from which one can perform a query based on surnames. After deleting names that were not Armenian or names with no address, we were left with over 78,000 names (or telephone numbers). ${ }^{5}$ From this, a random sample of 6,900 names was drawn, including 900 names for purpose of survey pre-tests.

Three pre-tests were conducted mainly to test for the sensitivity of the hypothetical scenario, the sensitivity of respondents to personal questions (i.e. income, transfers to relatives abroad, etc), as well as to construct the appropriate upper bounds of the bidding structure. ${ }^{6}$ Of the first pre-test results $(n=100)$, the most significant issue was a significant level of non-response. To boost the response rate, a multiple-contact strategy was then adopted following the experience of Dillman (2000), where the respondent was initially sent an invitation letter explaining the purpose of the survey and asked whether or not they would be willing to participate in the study. ${ }^{7}$ The respondent was then asked to return the postage paid card. Once received, respondents who replied "yes" to the participation question were then sent a survey package with a postage paid return envelope. The survey package included a simple cover explaining the historical evolution of Lake Sevan's condition, along with a visual aid and survey. If no response

\footnotetext{
${ }^{4}$ In addition to "ian", another ending, though much less frequent, is 'yan'. However, this suffix is not unique to the Armenian population. Armenians with names not ending in "ian" were excluded from our sample set. The nature of the sample selection bias thus introduced, if any, is not clear. A few exceptions to this rule were found, for example, the surnames "Christian", "Sebastian", and "Subramanian" are not of Armenian descent. These were eliminated from the final sample set.

${ }^{5}$ The original name extraction from Powerfinder yielded 194,253 names with the suffix 'ian'. Using Armenian genealogical web sites and surname search routines, we were able to delete names that were obviously not Armenian (e.g. Subramanian), narrowing the sample to approximately 130,123 names. We then subtracted names that had no corresponding phone number, zip code, or contained the words 'nonsolicit' in the phone directory column (e.g. households indicating this option to avoid telemarketers). We also subtracted duplicate addresses to avoid phoning (mailing) the same household that had multiple lines. The net result was 78,247 names.

${ }^{6}$ The upper bound of the bidding structure was set such that no more than $3 \%$ of the sample would respond "yes" to the suggested maximum bid amount. The final maximum bid retained in the study was 10,000 USD.

${ }^{7}$ A 5-piece correspondence strategy was tested and ultimately used, including an invitation letter, survey package, postcard reminder, follow-up survey package and a final contact letter.
} 
was encountered after a specified period of time, follow-up telephone calls were placed to the respondent until a definite answer was given. The detailed procedure is presented in Appendix II.

Of the 6,000 invitation cards sent to US respondents, 1,352 (23\%) agreed to participate in the survey, and of these, 389 (29\%) were returned completed.

\section{III.2 Questionnaire}

The questionnaire includes six parts: 1) environmental attitudes and perceptions; 2) a description of the Lake Sevan action plan; 3) support for environmental improvements to Lake Sevan; 4) socio-economic characteristics; 5) cultural aspects; and 6) use of Lake Sevan. In the third section of the survey, the impact of the action plan on Lake Sevan was thoroughly discussed and presented with charts which compared the current situation with the situation with and without action plan. Information about the costs of the action plan and the plan implementation was also provided.

The respondent was asked to assume to pay a one-time donation to a trust fund established for the implementation of the action plan, administered by a Board of governors comprising various and reputed interest groups so as to minimize any possible bias.

A dichotomous choice contingent valuation format was employed with a bid range from US\$20 to US\$10,000. ${ }^{8}$ A maximum WTP question and a level of certainty question followed the dichotomous choice question. Follow-up questions were also asked to assess the respondents' judgment of support of Armenians for the action plan, the feasibility of reaching the target of the action plan, the change of the historical, cultural and symbolic value of the lake with the protection of the lake, the change of water quality, the change in the quality of the ecosystem, the change of the lake for recreational

\footnotetext{
${ }^{8}$ The complete bid range was: [ $\left.\$ 20, \$ 50, \$ 100, \$ 200, \$ 500, \$ 800, \$ 1000, \$ 2000, \$ 5000, \$ 10000\right]$.
} 
use, and their confidence in the trust fund management and in the implementation of the action plan. Excerpts of the survey are presented in Appendix III. 


\section{III.3 Statistics}

Table 1 provides the definition of the major variables used in the analysis. Mean values are provided in Table 2.

Table 1 Variable Description

\begin{tabular}{|c|c|c|c|}
\hline Variable: & Description/Question: & Type: & Coded: \\
\hline $\begin{array}{l}\text { WTP } \\
\text { (dependent variable) }\end{array}$ & $\begin{array}{l}\text { "If your HH were asked to donate x USD, would } \\
\text { you support the plan?" }\end{array}$ & Discrete & $0=\mathrm{No} / \mathrm{DK} ; 1=$ Yes \\
\hline Bid & Bid amount & Discrete & $\begin{array}{l}20,50,100,200,500,800 \\
1000,2000,5000,10000\end{array}$ \\
\hline Version & Survey version: 0 or 3 meters & Dummy & $0=0 \mathrm{~m} ; 1=3 \mathrm{~m}$ \\
\hline Symbol & $\begin{array}{l}\text { "How would you project the change of the } \\
\text { historical, cultural and symbolic value of Lake } \\
\text { Sevan with the increase in water level by x } \\
\text { meters?" }\end{array}$ & Categorical & $\begin{array}{l}-2=A \text { lot worse } \\
-1=A \text { little worse } \\
0=\text { No change } \\
1=A \text { little improvement } \\
\text { 2=A large improvement } \\
\text { 99=Don't know }\end{array}$ \\
\hline Water quality & $\begin{array}{l}\text { "How would you project the change of water } \\
\text { quality with the increase in water level by x } \\
\text { meters?" }\end{array}$ & Categorical & Same as directly above. \\
\hline Ecosystem & $\begin{array}{l}\text { "How would you project the change in the quality } \\
\text { of the lake ecosystem, including fish, birds and } \\
\text { grass, etc., with the increase of water level by x } \\
\text { meters?" }\end{array}$ & Categorical & Same as directly above. \\
\hline Recreate & $\begin{array}{l}\text { "How would you project the change of the quality } \\
\text { of the lake for recreational use associated with an } \\
\text { increase in water level by x meters?" }\end{array}$ & Categorical & Same as directly above. \\
\hline Implement & $\begin{array}{l}\text { "With your understanding of the current situation } \\
\text { in Armenia, do you think that the action plan as we } \\
\text { described before can be implemented?" }\end{array}$ & Categorical & $\begin{array}{l}-2=\text { Definitely not } \\
-1=\text { Probably not } \\
0=\text { Neutral } \\
1=\text { Probably yes } \\
2=\text { Definitely yes } \\
99=\text { Don't know }\end{array}$ \\
\hline Board & $\begin{array}{l}\text { "Do you think that the governing board of the Trust } \\
\text { Fund as we described before can do a good job in } \\
\text { managing the implementation of the action plan?" }\end{array}$ & Categorical & Same as directly above. \\
\hline Easiness & $\begin{array}{l}\text { "The target of this action plan is to increase the } \\
\text { water level by } x \text { meters in } z \text { years. How easy or } \\
\text { difficult do you think it will be to reach this target } \\
\text { by implementing this plan? }\end{array}$ & Categorical & $\begin{array}{l}-2=\text { Very difficult } \\
-1=\text { Difficult } \\
0=\text { Neutral } \\
1=\text { Easy } \\
2=\text { Very easy } \\
99=\text { Don't know }\end{array}$ \\
\hline Past use & "Have you ever seen Lake Sevan in your life? & Dummy & $0=\mathrm{No} ; 1=\mathrm{Yes}$ \\
\hline Current use & $\begin{array}{l}\text { "Have you visited Lake Sevan in the past } 12 \\
\text { months?" }\end{array}$ & Dummy & $0=\mathrm{No} ; 1=\mathrm{Yes}$ \\
\hline Future use & "Do you think your household will ever use the & Dummy & $0=$ No; $1=$ Yes; 99=Don't know \\
\hline
\end{tabular}




\begin{tabular}{|c|c|c|c|}
\hline Variable: & Description/Question: & Type: & Coded: \\
\hline & lake for recreational purposes in the future?" & & \\
\hline Certainty & $\begin{array}{l}\text { Uncertain about the answers to the questions about } \\
\text { change of the value of the lake, the implementation } \\
\text { of the action plan and use of the lake }\end{array}$ & Dummy & $\begin{array}{l}\text { Each index recoded as: } \\
1=\text { Don't know } \\
0=\text { Otherwise }\end{array}$ \\
\hline Plan knowledge & "Have you ever heard about this Action Plan?" & Categorical & $\begin{array}{l}0=\text { No } \\
1=\mathrm{I} \text { have heard a little bit. } \\
2=\text { Yes, I have heard a lot. }\end{array}$ \\
\hline Media (lake) & $\begin{array}{l}\text { "How often have you heard about environmental } \\
\text { problems with Lake Sevan on TV, the radio, } \\
\text { newspapers, magazines, or by community groups } \\
\text { in the last } 12 \text { months?" }\end{array}$ & Categorical & $\begin{array}{l}0=\text { Never } \\
3=\text { A few times }(1-5) \\
8=\text { Several times }(6-10) \\
15=\text { Many times }(11-20) \\
20=\text { More than } 20 \text { times }\end{array}$ \\
\hline Income & & Continuous & \\
\hline Gender & & Dummy & $0=$ Female $; 1=$ Male \\
\hline Age & & Continuous & \\
\hline Household size & & Continuous & \\
\hline Education & Education & Categorical & $\begin{array}{l}0=\text { Never attended school } \\
5=\text { Grade school (grades } 1-9) \\
10=\text { Some high school } \\
12=\text { High school graduate } \\
14=\text { College or technical school } \\
14=\text { Some university } \\
16=\text { Undergraduate degree } \\
20=\text { Graduate courses or degree }\end{array}$ \\
\hline Charity & $\begin{array}{l}\text { "Did you ever make a \$ contribution to an } \\
\text { Armenian community group or church?" + } \\
\text { "Did you ever make a \$ contribution to an } \\
\text { environmental organization or NGO?" + } \\
\text { "Did you ever make a \$ donation to relief efforts or } \\
\text { projects in Armenia?" }\end{array}$ & Dummy & $0=$ No $; 1=$ Yes \\
\hline Armenian & "What is your current nationality?" & Dummy & $0=$ Other; $1=$ Armenian \\
\hline US born & "Were you born in the United States?" & Dummy & $0=\mathrm{No} ; 1=\mathrm{Yes}$ \\
\hline Parents & "What nationality is your mother/father?" & Dummy & $\begin{array}{l}0=\text { Other; } 1=\text { One parent is } \\
\text { Armenian; } 2=\text { Both parents are } \\
\text { Armenian }\end{array}$ \\
\hline Relatives & "Do you have any family or relatives in Armenia?" & Dummy & $0=$ No; $1=$ Yes \\
\hline Church & $\begin{array}{l}\text { "Do you belong to any community groups or a } \\
\text { church?" }\end{array}$ & Dummy & $0=\mathrm{No} ; 1=$ Yes \\
\hline Transfer funds & $\begin{array}{l}\text { "Did you ever transfer funds to relatives or friends } \\
\text { in Armenia?" }\end{array}$ & Dummy & $0=$ No $; 1=$ Yes \\
\hline East & $\begin{array}{l}\text { Whether the respondent was located in an Eastern } \\
\text { state. }\end{array}$ & Dummy & $0=$ No $; 1=$ Yes \\
\hline Time & $\begin{array}{l}\text { Length of time (years) since leaving Armenia } \\
\text { (either by self, or parents) }\end{array}$ & Continuous & \\
\hline
\end{tabular}

The average household annual income of the respondents is approximately 68,600 USD. About $70 \%$ of the respondents are male. The average age of the respondents is 52 and the average education is with college degree. It was found that $43.4 \%$ of the 
respondents are of Armenian nationality (citizenship), and that $33.2 \%$ of the respondents have relatives or other family members who are currently living within Armenia. 13.4\% of the respondents actually transfer funds to relatives or friends in Armenia. A slight majority $(58.9 \%)$ of the respondents belong to a community group or a church.

In our sample, $32 \%$ of the respondents have seen Lake Sevan, and $25 \%$ of the respondents are indicating that they may use Lake Sevan in the future for recreational purposes.

Most respondents believe that with the Lake Sevan protection action plan, the historical, cultural and symbolic value of the lake, the water quality of the lake, the quality of the ecosystem of the lake, as well as the quality of lake for recreational use would be improved. 
Table 2

Descriptive Statistics

\begin{tabular}{lrrr}
\hline Variable & Mean & Minimum & Maximum \\
\hline WTP (dep. Variable) & 0.332 & 0 & 1 \\
Bid & $1,637.481$ & 20 & 10,000 \\
Version & 0.486 & 0 & 1 \\
Symbol & 1.175 & -2 & 2 \\
Water quality & 1.147 & -2 & 2 \\
Ecosystem & 1.379 & -2 & 2 \\
Recreate & 1.170 & -2 & 2 \\
Implement & 0.456 & -2 & 2 \\
Board & 0.739 & -1 & 2 \\
Easiness & -0.409 & -2 & 2 \\
Past use & 0.325 & 0 & 1 \\
Current use & 0.055 & 0 & 1 \\
Future use & 0.255 & 0 & 1 \\
Certainty & 1.732 & 0 & 9 \\
Plan knowledge & 0.302 & 0 & 2 \\
Media (lake) & 2.680 & 0 & 20 \\
Income & $68,594.090$ & 6,000 & 350,000 \\
Gender & 0.717 & 0 & 1 \\
Age & 52.919 & 18 & 93 \\
Household size & 2.584 & 1 & 7 \\
Education & 16.654 & 5 & 20 \\
Charity & 1.555 & 0 & 3 \\
Armenian & 0.434 & 0 & 1 \\
US born & 0.636 & 0 & 1 \\
Parents & 1.154 & 0 & 2 \\
Relatives & 0.332 & 0 & 1 \\
Church & 0.589 & 0 & 1 \\
Transfer funds & 0.134 & 0 & 1 \\
East & 0.728 & 0 & 1 \\
Time & 48.170 & 0 & 103 \\
\hline
\end{tabular}

Table 3 presents the statistics of the answers to the WTP questions. As is shown, the survey gives a reasonable distribution of the yes answers over the range of the bids. 
Table 3

Bid Response to WTP Questions

\begin{tabular}{ccccc}
\hline & \multicolumn{2}{c}{ 0 meter } & \multicolumn{2}{c}{ 3 meter } \\
Bid & \% Yes & \# surveys & \% Yes & \# surveys \\
\hline 20 & 71 & 17 & 82 & 17 \\
50 & 67 & 15 & 70 & 23 \\
100 & 60 & 30 & 54 & 24 \\
200 & 30 & 20 & 58 & 24 \\
500 & 14 & 22 & 22 & 18 \\
800 & 18 & 22 & 23 & 22 \\
1000 & 7 & 15 & 18 & 17 \\
2000 & 12 & 25 & 14 & 14 \\
5000 & 0 & 20 & 6 & 17 \\
10000 & 0 & 14 & 0 & 13 \\
Total & 29 & 200 & 38 & 189 \\
\hline
\end{tabular}

\section{Willingness-to-pay Estimation}

\section{IV.1 WTP model}

Following the traditional WTP estimation procedure for the dichotomous choice contingent valuation data, a standard probit model can be used to calculate the willingness to pay for each of the sub-samples in the US. Assume that:

\section{(1) $\quad \mathrm{WTP}=\alpha+\mathrm{X}_{i}^{\prime} \beta+\varepsilon_{\mathrm{i}}$}

Then, the probability for a person to give a "yes" answer to the dichotomous contingent valuation question with a price $t_{i}$ is:

$$
\begin{aligned}
\operatorname{Pr}(\text { Yes }) & =\operatorname{Pr}\left(\alpha+X_{i}^{\prime} \beta+\varepsilon_{i}>t_{i}\right) \\
& =\operatorname{Pr}\left(\varepsilon_{i}>t_{i}-\alpha-X_{i}^{\prime} \beta\right) \\
& =1-\Phi\left[\left(t_{i}-\alpha-X_{i}^{\prime} \beta\right) / \sigma\right]
\end{aligned}
$$

and the probability of giving a "no" answer is: 


$$
\begin{array}{ll}
\operatorname{Pr}(\mathrm{No}) \quad & \operatorname{Pr}\left(\alpha+\mathrm{X}_{\mathrm{i}}^{\prime} \beta+\varepsilon_{\mathrm{i}}<\mathrm{t}_{\mathrm{i}}\right) \\
& =\Phi\left[\left(\mathrm{t}_{\mathrm{i}}-\alpha-\mathrm{X}_{\mathrm{i}}^{\prime} \beta\right) / \sigma\right]
\end{array}
$$

where, $X_{i}$ is the vector of WTP determinants, $\beta$ is the vector of coefficients to be estimated, $t_{i}$ is the price offered to respondent $i$, and $\Phi$ is the cumulative standard normal distribution function, and $\varepsilon_{\mathrm{i}}$ is a random error with a distribution $\mu\left(0, \sigma^{2}\right)$. The $\log$ likelihood function can be constructed as:

$$
\begin{aligned}
\ln \mathrm{L} & =\Sigma\left\{\mathrm{y}_{\mathrm{i}} * \ln \operatorname{Pr}(\mathrm{Yes})+\left(1-\mathrm{y}_{\mathrm{i}}\right) * \ln \operatorname{Pr}(\mathrm{No})\right\} \\
& =\Sigma\left\{\mathrm { y } _ { \mathrm { i } } * \operatorname { l n } \left[1-\Phi\left[\left(\mathrm{t}_{\mathrm{i}}-\alpha-\mathrm{X}_{\mathrm{i}}^{\prime} \beta\right) / \sigma\right]+\left(1-\mathrm{y}_{\mathrm{i}}\right) * \ln \left[\Phi\left[\left(\mathrm{t}_{\mathrm{i}}-\alpha-\mathrm{X}_{\mathrm{i}}^{\prime} \beta\right) / \sigma\right]\right\}\right.\right.
\end{aligned}
$$

Variables that may influence the Armenian Diaspora's WTP can be categorized into five broad groups as specified in Table I. The first set of variables (Symbol, Water quality, Ecosystem, Recreate) relate directly to the commodity, Lake Sevan. The purpose of including these variables is to capture any lake-specific effects that the respondent may view as being important in their willingness to pay. The second set of variables (Implement, Board, Easiness) are included to capture the effects the implementation of Lake Sevan Action Plan may have on respondent behavior, which relates to the delivery of the commodity. The third set of variables (Past use, Current use, Future use) measure the use or potential use factor of the lake. The fourth set of variables (Plan knowledge, Media (lake)) are included to capture the relative visibility of the plan and Lake Sevan issues among the population (i.e. have they heard of the plan or Lake Sevan in the news). The fifth broad set of variables (Income, Gender, Age, Household size, Education, Charity, Armenian, US born, Parents, Relatives, Church, Transfer funds, East, Time) are individual-specific variables that measure the socio-economic variability among the respondents. More specifically, the latter set of variables after Education provide a measure of the degree of removal (or connection) of the individual to Armenia. 


\section{IV.2 Results}

The modeling results are presented in Table 4. The average WTP for the 3-meter case is estimated to be $\$ 281.1$ with the simplest constant model, and the average WTP for the 0 -meter case is about $\$ 80.8$.

Given the nature of the existing analysis, it is of significant interest to note that individuals who believe the Lake Sevan action plan can generate positive changes in the historical, cultural and symbolic values of the lake would be willing to donate more for the action plan implementation. Furthermore, the coefficient of the variable "Version" is positive and significant, which implies that people are willing to pay more for the case of increasing water level by 3 meters than for the case of preventing the water level from decreasing, even after the specified WTP determinants have been controlled in the model.

Perhaps as it may be expected, individuals who have actually seen Lake Sevan in the past would be willing to donate more to facilitate the implementation of the Lake Sevan action plan. ${ }^{9}$ However, our results also indicate a higher willingness to donate from those individuals who may anticipate experiencing recreational activities at Lake Sevan in the future. To this extent, the restoration of Lake Sevan appears to have both non-use (symbolic) and use (option) values for the Armenian Diaspora in the United States.

\footnotetext{
${ }^{9}$ The "Future use" variable can also be loosely interpreted as an option value, measuring an individual's willingness to pay to preserve the option of using the lake in the future.
} 
Table 4

WTP Modeling Results

\begin{tabular}{|c|c|c|c|}
\hline $\begin{array}{l}\text { Dependent } \\
\text { variable: WTP }\end{array}$ & Coefficient & Standard errors & $\mathbf{Z}$ \\
\hline Bid & $-0.0009 * * *$ & 0.0002 & -5.81 \\
\hline Version & $0.4328 * *$ & 0.1899 & 2.28 \\
\hline Symbol & $0.2582 * *$ & 0.1275 & 2.02 \\
\hline Water quality & -0.0386 & 0.1534 & -0.25 \\
\hline Ecosystem & -0.0838 & 0.1789 & -0.47 \\
\hline Recreate & 0.1464 & 0.1364 & 1.07 \\
\hline Implement & 0.1024 & 0.1145 & 0.89 \\
\hline Board & 0.2041 & 0.1443 & 1.41 \\
\hline Easiness & -0.1308 & 0.1348 & -0.97 \\
\hline Past use & $0.5040 * *$ & 0.2334 & 2.16 \\
\hline Current use & 0.7951 & 0.5291 & 1.50 \\
\hline Future use & $0.8905 * * *$ & 0.3187 & 2.79 \\
\hline Certainty & -0.0273 & 0.0620 & -0.44 \\
\hline Plan knowledge & 0.0601 & 0.2252 & 0.27 \\
\hline Media (lake) & -0.0135 & 0.0236 & -0.57 \\
\hline Income & $0.000008 * * *$ & 0.000002 & 3.99 \\
\hline Gender & -0.0275 & 0.2096 & -0.13 \\
\hline Age & 0.0050 & 0.0074 & 0.68 \\
\hline Household size & -0.0624 & 0.0752 & -0.83 \\
\hline Education & 0.0311 & 0.0287 & 1.08 \\
\hline Charity & $0.2784 * *$ & 0.1139 & 2.44 \\
\hline Armenian & -0.1932 & 0.2275 & -0.85 \\
\hline Us born & $-0.5946 * *$ & 0.2882 & -2.06 \\
\hline Parents & 0.1252 & 0.1273 & 0.98 \\
\hline Relatives & 0.1570 & 0.2604 & 0.60 \\
\hline Church & $-0.3911 *$ & 0.2224 & -1.76 \\
\hline Transfer funds & 0.1430 & 0.3299 & 0.43 \\
\hline East & -0.0766 & 0.2106 & -0.36 \\
\hline Time & 0.0054 & 0.0044 & 1.22 \\
\hline Constant & $-2.3718 * * *$ & 0.8125 & -2.92 \\
\hline Log-likelihood & -136.07 & & \\
\hline $\mathbf{R}^{2^{\circ}}$ & 0.4494 & & \\
\hline $\mathbf{N}$ & 389 & & \\
\hline
\end{tabular}

Income is another significant variable in the willingness-to-pay model, as is charity, which would imply that the willingness to donate for Lake Sevan restoration is higher if a person also donated for other Armenia or environment related activities in the past. Note that being a US born citizen negatively impacts the willingness to donate, as does membership in an Armenian church. It is not immediately clear why such 
membership would have this negative impact on the willingness to pay. Other variables do not show significant impacts on WTP answers.

\section{Conclusion}

In this paper, we have estimated the willingness to pay of the US-Armenian Diaspora to protect a crucial component of Armenian's cultural heritage, Lake Sevan. We believe this paper provides a significant contribution to the literature on the economics of cultural heritage not only by explicitly targeting members of a Diaspora, but also by considering an environmental asset as cultural heritage.

It may be of interest to conclude this paper with potential policy implications. As indicated at the outset of this paper, existing cost-benefit analyses of various protection options have estimated a negative net present value ranging from 72 to 147 million dollars. In this paper, the estimated household WTP range from 81 to 281 dollars. The best available statistics indicate that a population of approximately 1 million individuals of Armenian origin currently live in the United States. Using an average household size of 2.6 people (as measured in the existing survey), this would indicate the presence of approximately 385,000 households. If each were willing to provide a one-time donation equivalent to the average WTP estimated in this paper, this would represent between 31 and 108 million dollars. While this number would not offset the largest of the negative net present values presented above, it may offset the smallest of these values. Hence, the Lake Sevan restoration action plan may be interesting from an economic point of view when accounting for the willingness to donate by the Armenian Diaspora in the United States, and may also be financially feasible.

Two further issues remain of interest. First, the Armenian Diaspora is not solely limited to the United States. As indicated in Section II, a significant Diaspora is also found in France, the Middle East, and NIS countries. In this paper, we have not attempted to assess the WTP of this Diaspora. Furthermore, it is not known whether the results 
obtained in the United States could be extended and extrapolated to the Armenian Diaspora located outside of the United States. This should be the object of further research.

Second, while the results obtained in this paper may justify the protection of Lake Sevan, a crucial issue facing the Government of Armenia pertains to actually capturing the WTP estimated in the United States for the purpose of financing such protection activities. We have not attempted in this paper to address this important financing issue. 


\section{References}

Beltrán, E. and M. Rojas. 1996. Diversified funding methods in Mexican archeology. Annals of Tourism Research 23(2): 463-78.

Bølling, J. and V. Iversen. 1999. Tourists' willingness to pay for restoration of stone town to its original state and stopping habitat destruction in Jozani Forest Reserve, Zanzibar. M.Sc. Thesis, Department of Economics and Social Sciences, Agricultural University of Norway.

Boxall, P. C., J. Englin and W. Adamowicz. 1998. Valuing undiscovered attributes: a combined revealed-stated preference analysis of North American aboriginal artifacts. Paper presented at the First World Congress of Environmental and Resource Economists. June 25-27, 1998, Venice, Italy.

Carson, R. T., R. Mitchell, M. Conaway and S. Navrud. 1997. Non-Moroccan Values for Rehabilitating the Fes Medina. Report to the World Bank on the Fes Medina Cultural Heritage Rehabilitation Project.

Coulton, J. C. 1999. Optimal cultural heritage allocation: A model and contingent valuation study. M.Sc. Thesis, Environmental and Resource Economics Program, University College London.

Dillman, D. A. 2000. Mail and Internet Surveys: The Tailored Design Method. 2nd Edition. John Wiley Co.: New York.

Dixon, J. 1998. Estimating economic rents from tourism in Jordan. World Bank: Washington, DC. Mimeograph. Available at: http://nweb18.worldbank.org/ESSD/ envext.nsf/44ByDocName/EstimatingEconomicRentsfromTourisminJordan199895KP DF/\$FILE/EstimatingEconomicRentsfromTourisminJordan1998.pdf.

Garrod, G. D., K. G. Willis, H. Bjarnadottir and P. Cockbain. 1996. The non-priced benefits of renovating historic buildings: A case study of Newcastle Grainger Town. Cities 13(6): 423-30.

Grosclaude, P. and N. C. Soguel. 1994. Valuing damage to historic buildings using a contingent market: A case study of road traffic externalities. Journal of Environmental Planning and Management 37(3): 279-87.

Hansen, T. 1997. The willingness to pay for the Royal Theatre in Copenhagen as a public good. Journal of Cultural Economics 21(1): 1-28.

Harless, D. W. and F. R. Allen. 1999. Using the contingent valuation method to measure patron benefits of reference desk service in an academic library. College and Research Libraries 60(1): 56-69. 
Hett, T. and S. Mourato. 2000. Sustainable management of Machu Picchu: A stated preference approach. Department of Environmental Science and Technology, Imperial College of Science, Technology, and Medicine, London. Mimeograph.

Holt, G. E., D. Elliott and A. Moore. 1999. Placing a value on public library services. Public Libraries pp. 98-108.

Iwaco B.V. 1997. Cost-benefit analysis of completing the Vorotan Tunnel and least cost analysis of measures to raise Lake Sevan's water level. Final Report. Division International Projects, Rotterdam.

Kling, R., C. Revier and K. Sable. 2000. Estimating the public good value of preserving a local historic landmark: The role of non-substitutability and information in contingent valuation. Paper presented to the Association for Cultural Economics Conference, Minneapolis.

Lockwood, M., P. Tracey and N. Klomp. 1996. Analyzing conflict between cultural heritage and nature conservation in the Australian Alps: A CVM approach. Journal of Environmental Planning and Management 39(3): 357-370.

Maddison, D. and T. Foster. 2001. Valuing congestion in the British Museum. Department of Economics, University College London. Mimeograph.

Maddison, D. and S. Mourato. 2002. Valuing different road options for Stonehenge. In S. Navrud and R. Ready (eds.) Valuing Cultural Heritage: Applying Environmental Valuation Techniques to Historic Buildings, Monuments and Artifacts. Cheltenham: Edward Elgar.

Martin, F. 1994. Determining the size of museum subsidies. Journal of Cultural Economics 18(4): 255-70.

Morey, E., K. Rossmann, L. Chestnut and S. Ragland. 2002. Valuing reduced acid deposition injuries to cultural resources: marble monuments in Washington, DC. In S. Navrud and R. Ready (eds.) Valuing Cultural Heritage: Applying Environmental Valuation Techniques to Historic Buildings, Monuments and Artifacts. Cheltenham: Edward Elgar.

Mourato, S., A. Kontoleon and A. Danchev. 2002. Preserving cultural heritage in transition economies: A contingent valuation study of Bulgarian monasteries. In S. Navrud and R. Ready (eds.) Valuing Cultural Heritage: Applying Environmental Valuation Techniques to Historic Buildings, Monuments and Artifacts. Cheltenham: Edward Elgar. 
Navrud, S. and J. Strand. 2002. Social costs and benefits of preserving and restoring the Nidaros Cathedral. In S. Navrud and R. Ready (eds.) Valuing Cultural Heritage: Applying Environmental Valuation Techniques to Historic Buildings, Monuments and Artifacts. Cheltenham: Edward Elgar.

Noonan, D. 2002. Contingent valuation studies in the arts and culture: An annotated bibliography. Working paper. The Cultural Policy Center, University of Chicago.

Pagiola, S. 1999. Valuing the benefits of investments in cultural heritage: The historic core of Split. World Bank: Washington, DC. Mimeograph. Available at: http://nweb18.worldbank.org/ESSD/envext.nsf/44ByDocName/EconomicAnalysisofC onservationoftheHistoricCenterofSplitCroatia199896KPDF/\$FILE/EconomicAnalysiso fConservationoftheHistoricCenterofSplitCroatia1998.pdf.

Pollicino, M. and D. Maddison. 2001. Valuing the benefits of cleaning Lincoln Cathedral. Journal of Cultural Economics 25(2): 131-48.

Powe, N. A. and G. K. Willis. 1996. Benefits received by visitors to heritage sites: A case study of Warkworth Castle. Journal of Environmental Planning and Management 15(5): 611-19.

PowerFinder. 2001. 2001 Edition. InfoUSA Inc.: New England, USA.

Riganti, P. and K. Willis. 2002. Component and temporal value reliability in cultural goods: The case of Roman Imperial remains near Naples. In S. Navrud and R. Ready (eds.) Valuing Cultural Heritage: Applying Environmental Valuation Techniques to Historic Buildings, Monuments and Artifacts. Cheltenham: Edward Elgar.

Roche Rivera, H. 1998. The willingness to pay for a public mixed good: The Colón Theatre in Argentina. Paper presented at the Tenth International Conference on Cultural Economics, Barcelona, 14-17 June.

Sanatgata, W. and G. Signorello. 2000. Contingent valuation and cultural policy design: The case of Napoli Musei Aperti. Journal of Cultural Economics 24(3): 181-204.

Scarpa, R., G. Sirchia and M. Bravi. 1998. Kernel vs. Logit modeling of single bounded CV responses: Valuing access to architectural and visual arts heritage in Italy. In R. C. Bishop and D. Romano (eds.) Environmental Resource Evaluation: Application of the Contingent Valuation Method to Italy. Amsterdam: Kluwer Academic Publisher.

Throsby, C. and G. Withers. 1986. Strategic bias and the demand for public goods. Journal of Public Economics 31: 307-27. 
Whitehead, J., C. Chambers and P. Chambers. 1998. Contingent valuation of quasi-public goods: Validity, reliability, and application to valuing a historic site. Public Finance Review 26: 137-54.

Willis, K. G. 1994. Paying for heritage: What price for Durham Cathedral? Journal of Environmental Planning and Management 37(3): 267-77. 


\section{Appendix 1 \\ Cultural Heritage and Valuation Studies}

\begin{tabular}{|c|c|c|c|}
\hline Studies & Nature of respondents & $\begin{array}{l}\text { Number of } \\
\text { respondents }\end{array}$ & Comparison of WTP* \\
\hline $\begin{array}{l}\text { Arts support, Sydney } \\
\text { (Throsby and Withers, 1986) }\end{array}$ & - Local residents & 827 & $\begin{array}{l}\text { Consumers }>\text { Non- } \\
\text { consumers }\end{array}$ \\
\hline $\begin{array}{l}\text { British Museum } \\
\quad \text { (Maddison and Foster, 2001) }\end{array}$ & - Visitors to the museum & 400 & Not relevant \\
\hline $\begin{array}{l}\text { Cabell Library, Virginia } \\
\text { (Harless and Allen, 1999) }\end{array}$ & - Local staff and students & 382 & Not relevant \\
\hline $\begin{array}{l}\text { City of Split, Croatia } \\
\text { (Pagiola, 1999) }\end{array}$ & $\begin{array}{l}\text { - Local residents } \\
\text { - Domestic and foreign tourists }\end{array}$ & $\begin{array}{l}100 \text { local } \\
400 \text { tourists }\end{array}$ & Resident $>$ Tourist \\
\hline $\begin{array}{l}\text { Colón Theatre, Buenos Aires } \\
\qquad \text { (Roche Rivera, 1998) }\end{array}$ & - Local residents & 3,306 & Not relevant \\
\hline $\begin{array}{l}\text { Copenhagen Royal Theatre } \\
\qquad \text { (Hansen, 1997) }\end{array}$ & - Residents of Denmark & 1,843 & Not relevant \\
\hline $\begin{array}{l}\text { Durham Cathedral, Northumbria } \\
\text { (Willis, 1994) }\end{array}$ & $\begin{array}{l}\text { - Visitors of cathedral; } \\
\text { - No distinction between foreign and } \\
\text { nationals }\end{array}$ & 92 & Not relevant \\
\hline $\begin{array}{r}\text { Fes Medina, Morocco } \\
\text { (Carson, Mitchell, Conaway, and } \\
\text { Navrud (1997) }\end{array}$ & $\begin{array}{l}\text { - Foreign visitors of Fes Medina; } \\
\text { - Foreign visitors in Morocco }\end{array}$ & $\begin{array}{l}471 \text { Fes visitors } \\
126 \text { Morocco visitors }\end{array}$ & $\begin{array}{l}\text { Visitors to Fes }>\text { Visitors } \\
\text { of Morocco }\end{array}$ \\
\hline $\begin{aligned} \text { Grainger City, Northumbria } \\
\\
\text { (Garrod et al., 1996) }\end{aligned}$ & - Local residents of Granger Town & 162 & Not relevant \\
\hline $\begin{array}{l}\text { Historic buildings, Neuchâtel } \\
\quad \text { (Grosclaude and Soguel, 1994) }\end{array}$ & - Local residents & 200 & Not relevant \\
\hline $\begin{array}{l}\text { Lincoln Cathedral } \\
\quad \text { (Pollicino and Maddison, 2001) }\end{array}$ & $\begin{array}{l}\text { - Local residents from within the city, } \\
\text { and from outside the city }\end{array}$ & 328 & Inside city $>$ Outside city \\
\hline $\begin{array}{l}\text { Machu Picchu, Peru } \\
\text { (Hett and Mourato, 2000) }\end{array}$ & $\begin{array}{l}\text { - Visitors of site, both national and } \\
\text { foreign }\end{array}$ & 1,014 & Foreign $>$ National \\
\hline $\begin{array}{l}\text { Marble monuments of Washington, } \\
\text { DC } \\
\text { (Morey et al., 2002) }\end{array}$ & $\begin{array}{l}\text { - Residents of Boston and } \\
\text { Philadelphia }\end{array}$ & 259 & Not available \\
\hline $\begin{array}{l}\text { Musée de la Civilisation, Quebec, } \\
\text { Canada } \\
\text { (Martin, 1994) }\end{array}$ & - Not available & 1,231 & Not available \\
\hline $\begin{array}{l}\text { Napoli Musei Aperti } \\
\quad \text { (Sanatgata and Signorello, 2000) }\end{array}$ & - Local residents & 468 & Not relevant \\
\hline $\begin{array}{l}\text { Nidaros Cathedral, Norway } \\
\text { (Navrud and Strand, 2002) }\end{array}$ & $\begin{array}{l}\text { - Visitors of cathedral, both national } \\
\text { and foreign }\end{array}$ & $\begin{array}{l}84 \text { nationals } \\
79 \text { foreigners }\end{array}$ & National $>$ Foreigner \\
\hline $\begin{array}{l}\text { Northern Hotel, Fort Collins } \\
\quad \text { (Kling, Revier and Sable, 2000) }\end{array}$ & - Local residents & 252 & Not relevant \\
\hline $\begin{array}{l}\text { Petra and Wadi Rum, Jordan } \\
\text { (Dixon, 1998) }\end{array}$ & - Visitors to the sites & Not available & Not relevant \\
\hline $\begin{array}{l}\text { Prehistoric cave paintings, Peak } \\
\text { District, UK } \\
\text { (Coulton, 1999) }\end{array}$ & - Not available & Not available & Not relevant \\
\hline $\begin{array}{r}\text { St. Genevieve Academy, Missouri } \\
\text { (Whitehead, Chambers and } \\
\text { Chambers, 1998) }\end{array}$ & - Local residents & 132 & Not relevant \\
\hline $\begin{array}{l}\text { St. Louis Libraries, USA } \\
\text { (Holt, Elliott and Moore, 1999) }\end{array}$ & - Local residents & 336 & Not relevant \\
\hline $\begin{array}{l}\text { Stonehenge } \\
\quad \text { (Maddison and Mourato, 2002) }\end{array}$ & $\begin{array}{l}\text { - Visitors } \\
\text { - Residents of England with over- }\end{array}$ & $\begin{array}{l}271 \text { nationals on-site } \\
525 \text { nationals off-site }\end{array}$ & $\begin{array}{l}\text { On-site nationals }>\text { Off- } \\
\text { site nationals }>\text { On-site }\end{array}$ \\
\hline
\end{tabular}




\begin{tabular}{|c|c|c|c|}
\hline Studies & Nature of respondents & $\begin{array}{l}\text { Number of } \\
\text { respondents }\end{array}$ & Comparison of WTP* \\
\hline & $\begin{array}{l}\text { sampling of areas where Stonehenge } \\
\text { is located }\end{array}$ & 116 foreign on-site & foreigners \\
\hline $\begin{array}{l}\text { Stone Town, Zanzibar } \\
\text { (Bølling and Iversen, 1999) }\end{array}$ & - Tourists to the site & Not available & Not relevant \\
\hline $\begin{array}{l}\text { Two Italian museums (Rivoli } \\
\text { Castle) } \\
\text { (Scarpa, Sirchia and Bravi, 1998) }\end{array}$ & - Visitors of museums & 2,100 & Not relevant \\
\hline $\begin{array}{l}\text { Warkworth Castle, Northumbria } \\
\text { (Powe and Willis, 1996) }\end{array}$ & $\begin{array}{l}\text { - Visitors of castle; } \\
\text { - No distinction between foreign and } \\
\text { nationals }\end{array}$ & 97 & Not relevant \\
\hline $\begin{array}{l}\text { Aboriginal rock paintings } \\
\text { (Boxall, Englin and Adamowicz, } \\
2002)\end{array}$ & $\begin{array}{l}\text { - Visitors from } 5 \text { Canadian provinces } \\
\text { and } 3 \text { American states }\end{array}$ & 431 & $\begin{array}{l}\text { No distinction between } \\
\text { Canadian and American } \\
\text { visitors }\end{array}$ \\
\hline $\begin{array}{r}\text { Bulgarian monasteries } \\
\text { (Mourato, Kontoleon and } \\
\text { Danchev, 2002) }\end{array}$ & - Residents of Bulgaria & 483 & Not relevant \\
\hline $\begin{array}{l}\text { Cultural Heritage of grazing the } \\
\text { Australian alps } \\
\text { (Lockwood, Tracey and Klomp, } \\
1996)\end{array}$ & - Residents & 702 & Not relevant \\
\hline $\begin{array}{l}\text { Campi Flegrei archeological park, } \\
\text { Napoli } \\
\\
\text { (Riganti and Willis, 2002) }\end{array}$ & - On-site and off-site respondents & $\sim 800$ & Not available \\
\hline $\begin{array}{l}\text { Mexican archeological sites } \\
\text { (Beltrán and Rojas, 1996) }\end{array}$ & $\begin{array}{l}\text { - Local residents } \\
\text { - Visitors to the site }\end{array}$ & $\begin{array}{l}5,603 \text { residents } \\
900 \text { visitors }\end{array}$ & Residents $\geq$ Visitors \\
\hline
\end{tabular}

* Comparison between different subsets of the sample (e.g. national visitors vs. foreign visitors).

** This study did not estimate the WTP to observe aboriginal rock paintings but instead the willingness of visitors to undertake additional recreational trips if paintings were observable in the park. 


\section{Appendix II: Survey implementation procedure}

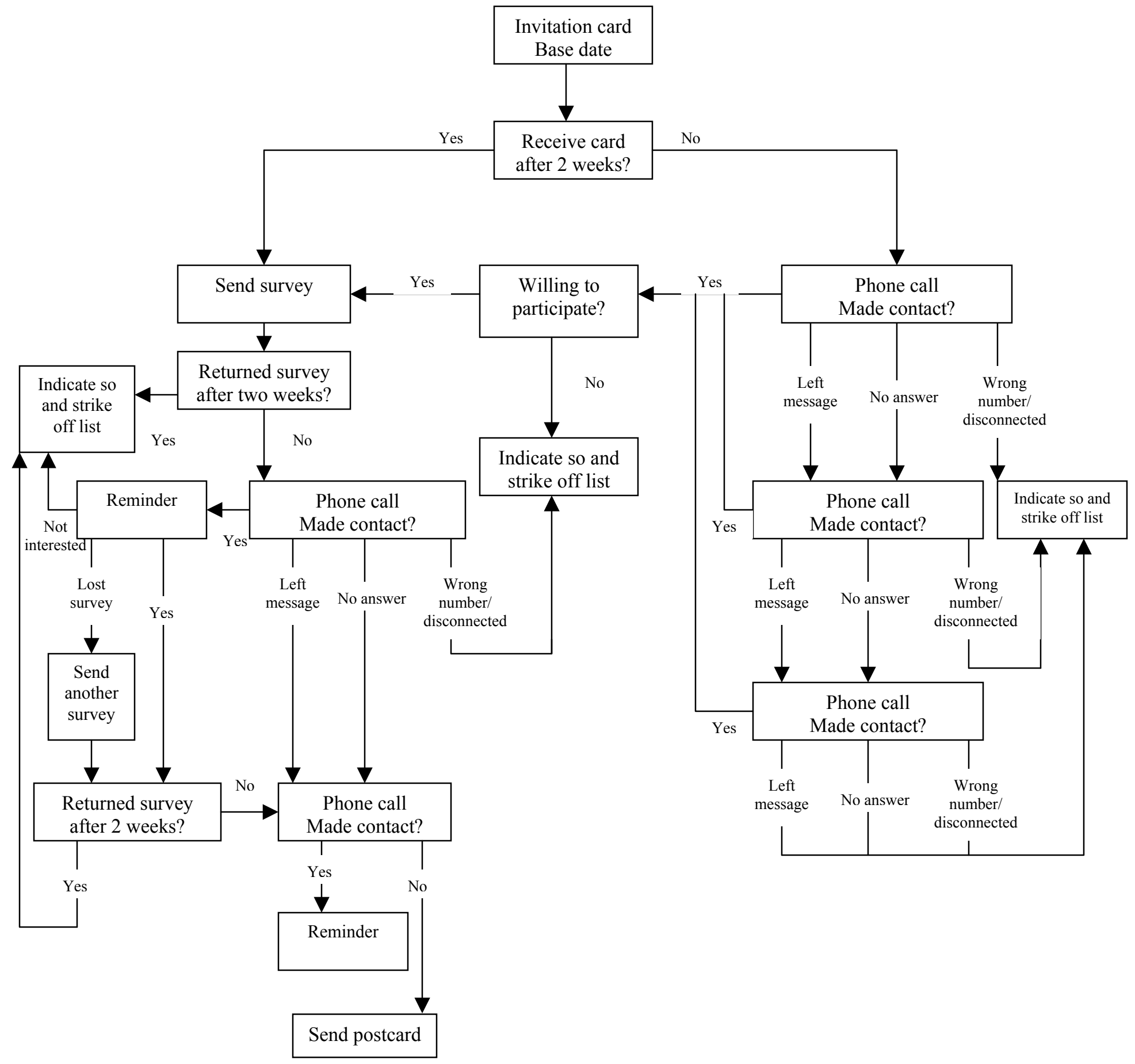




\section{Appendix III WTP Related Questions}

\section{$\underline{\text { Consequences of the Lake Sevan Protection Action Plan }}$}

Now please focus on the possibility of only Target \#1, stabilizing the level of the lake. To meet the target the action would be to limit annual water releases in such a way so as to keep the level of the lake constant.

Before making a decision on whether to support such an action plan, it would be helpful to know what all the consequences of stabilizing and preventing a further lowering of the lake would be to the environment and the economy. However, it would be difficult to predict precisely the effects of the Action Plan. Presented below is a general description of some of the expected consequences of stabilizing the level of the lake:

A. There would be no further water level decrease;

B. Water quality in the lake would not experience any further decrease;

C. Fish, bird and plant populations would not decrease;

D. Recreational and tourist activities would not decrease since there would be no decrease in water quality;

E. There would be no further decrease in the commercial fishery;

F. Water availability for agricultural irrigation in the future would experience no further decrease;

G. In the future, the stock of water to produce energy would experience no further decrease.

\section{Costs of the Action Plan}

In all likelihood there would be a cost to Armenians in Armenia in implementing this Lake Sevan Restoration Plan. In addition, some Armenians may be negatively affected by the action - limiting water releases from Lake Sevan in order to prevent a future lowering of the lake. Financial support from different groups of Armenians would be necessary and the Armenian Diaspora outside Armenia would also be asked to help finance this plan by making donations.

$\underline{\text { Plan Implementation }}$

To implement the Action Plan, a Lake Sevan Trust Fund would be established. The citizens of Armenia and the Diaspora would be asked to pay a one-time donation into the Trust Fund. The ONLY purpose of the Lake Sevan Trust Fund would be to finance the implementation of the action plan.

The Fund would be managed and administered by a Board of Governors comprising various interest groups so as to minimize any possible bias. The Board would consist of Armenians from within Armenia, and Armenians outside of Armenia. The Board would also include environmental and community groups from the USA, France and Armenia as well as local residents of the Sevan basin area. The Chairman of the Board would be a non-partisan individual, a known figure in the Armenian Diaspora, with a long and solid reputation. The activities of the Board would be completely transparent. An independent auditing of the Board would be performed every year, and made public. A summary of the total financial transactions would be 
widely and publicly available. You can thus have complete trust in the allocation of the money only and specifically toward protecting and restoring Lake Sevan.

\section{Current situation \& No Change}

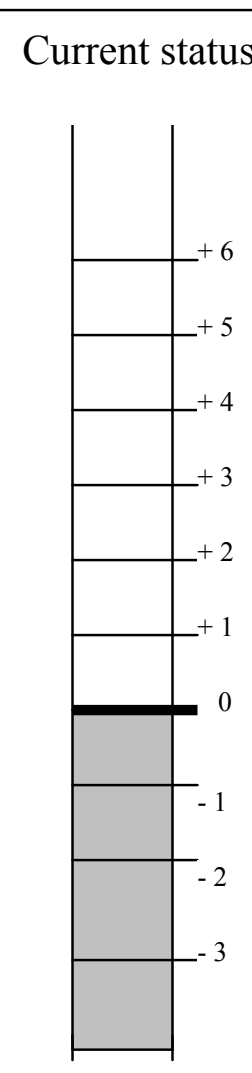

\section{No Action:
2 meter Decrease in 10 years}

\section{Expected impacts \\ Change (m)}

Fish: Decrease in general catch, and endemic trout become extinct

Birds: Continued decrease in bird species due to wetlands habitat destruction

Plants: Decreased number and variety of aquatic plants

Water quality: a lot worse

Power generation: small decrease today, larger decrease in the future

Agriculture irrigation: less water use today and even less availability in the future

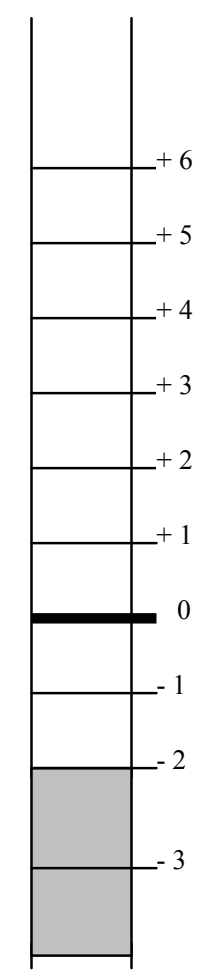


Considering your current income, as well as your expenses for housing, food, utilities, clothing, entertainment, savings, etc., please think about how much you would be willing to donate, onetime, to support the Lake Sevan Action Plan. Assume that your one time donation would be collected by a group of people delegated by the Trust Fund management.

11. If your household were asked to donate \$ USD to the Lake Sevan Trust Fund, would you support the plan to stabilize and prevent a further lowering of the lake?
$\square_{1}$ Yes
$\square_{2}$ No $\square_{99}$ I don't know

12. What then would be the maximum amount you are willing to donate to stabilize and prevent a further lowering of the lake? $\$$ USD $\square_{99}$ I don't know

13. How certain or sure are you of your stated willingness to donate in question 12 ?

$\begin{array}{ccccc}\square_{1} & \square_{2} & \square_{3} & \square_{4} & \square_{5} \\ \text { Very } & \text { Moderately } & \text { Neutral } & \text { Moderately } & \text { Very } \\ \text { Uncertain } & \text { Uncertain } & & \text { Certain } & \text { Certain }\end{array}$

Some people have told us they would support the Lake Sevan Action Plan to stabilize the level of the Lake because the restoration of Lake Sevan is a high priority for them. Others say they would not support the plan because they have so many other things to spend their money on. Some have said that the Action Plan would have to wait until the Armenian economy becomes stronger. Some people have also told us that they would not support the plan because they are not convinced that the money would be used for improvements in the lake.

14. Suppose that the cost of the Action Plan to people in Armenia were to be 0 (zero). How strong do you think support would be by the people of Armenia for the Action Plan to stabilize and prevent a further lowering of the lake?

$\begin{array}{cccccc}\square_{1} & \square_{2} & \square_{3} & \square_{4} & \square_{5} & \square_{99} \\ \text { Very } & \text { Moderately } & \text { Neutral } & \text { Moderately } & \text { Very } & \text { Don't } \\ \text { Weak } & \text { Weak } & & \text { Strong } & \text { Strong } & \text { Know }\end{array}$

15. The target of this action plan is to stabilize and prevent a further lowering of the lake. How easy or difficult do you think it will be to reach this target by implementing this plan?

$\begin{array}{cccccc}\square_{1} & \square_{2} & \square_{3} & \square_{4} & \square_{5} & \square_{99} \\ \text { Very } & \text { Easy } & \text { Not easy } & \text { Difficult } & \text { Very } & \text { Don't } \\ \text { Easy } & & \text { Not difficult } & & \text { difficult } & \text { Know }\end{array}$

16. How would you project the change of the historical, cultural and symbolic value of Lake Sevan by stabilizing and preventing a further lowering of the lake?

$\begin{array}{cccccc}\square_{1} & \square_{2} & \square_{3} & \square_{4} & \square_{5} & \square_{99} \\ \text { A lot worse } & \text { A little } & \text { No change } & \text { A little } & \text { A large } & \text { Don't Know } \\ & \text { worse } & & & \text { improvement } & \text { improvement }\end{array}$


17. How would you project the change of water quality by stabilizing and preventing a further lowering of the lake?
$\square_{1}$
A lot worse
$\begin{array}{cc}\square_{2} & \square_{3} \\ \text { A little } & \text { No change }\end{array}$
$\square_{4}$
A little
improvement improvement
Don't Know

18. How would you project the change in the quality of the lake ecosystem, including fish, birds and grass, etc., by stabilizing and preventing a further lowering of the lake?
A lot worse
$\square_{2}$
A little
worse
$\square_{3}$
No change
$\square_{4}$
A little
$\square_{5}$
A large
Don't Know
improvement improvement

19. How would you project the change of the quality of the lake for recreational use associated with stabilizing and preventing a further lowering of the lake?
A lot worse $\begin{array}{cc}\square_{2} & \square_{3} \\ \text { A little } & \text { No change } \\ \text { worse } & \end{array}$
$\square_{4}$
A little
$\square_{5}$
A large
$\square_{99}$
improvement improvement

20. Do you think that the governing board of the Trust Fund as we described before can do a good job in managing the implementation of the action plan?
$\boldsymbol{\square}_{1}$
Definitely
Probably
$\square_{3}$
Neutral
Probably
Yes
$\square_{5}$
Definitely
Yes
Don't Know
Not
Not

21. How realistic do you think it is for the Trust Fund management to collect donations from you as you may have agreed?

$\square_{1}$ No problem, it can be collected

$\square_{2}$ There will be some problems, but still possible

$\square_{3}$ There will be a lot of problems and it is not realistic

$\square_{99}$ I don't know

22. Do you think that if the action plan were to be implemented only by the Armenian government, it would be appropriately implemented?
$\square_{1}$
Definitely
Not
$\square_{2}$
Probably
Not
$\square_{3}$
$\square_{4}$
Probably
Yes
$\square_{5}$
Definitely
Yes
$\stackrel{\square_{99}}{\text { Don't Know }}$

23. With your understanding of the current situation in Armenia, do you think that the action plan as we described before can be finally implemented?
$\square_{1}$
Definitely
$\square_{2}$
Probably
$\square_{3}$
Neutral
$\square_{4}$
Probably
Yes
$\square_{5}$
Definitely
Yes
Don't Know
Not
Not
Yes

If you indicated that you are NOT willing to donate anything, please go to question 26. 
24. Considering your expenses such as food, clothing, savings, car, etc. is the donation you indicated previously a significant expense relative to your other bills and expenses?

\section{$\square_{1}$ Yes $\square_{2}$ No $\square_{99}$ I don't know}

25. Considering the maximum amount you are willing to donate and the potential decrease in the ability to pay other expenses, would you like to change your willingness to donate answer?

$\square_{1}$ Yes, I would like to change my answer (Go back to question 12 and change your answer) $\square_{2}$ No

$\square_{99}$ I don't know

26. What are the major reasons determining the maximum amount you are willing to donate for the Lake Sevan Action Plan? (even if your willingness to donate is zero)?

27. Would you like to have more information on anything before making your choice on how much to donate (For example, if you have any uncertainty about the plan, changes in the lake level, any environmental impacts, the trust fund, income, etc).

$\square_{2}$ No, I do not need any more information (Go to question 28)

$\square_{99}$ Don't know / Not sure (Go to question 28)

$\square_{1}$ Yes $\rightarrow 27.1$ What additional information would you like to have?

27.2 If we were able to provide more information on the items you listed above, would you be more certain about your willingness to donate or make your decision any easier?

$\square_{1}$ Yes $\quad \square_{2}$ No $\square_{99}$ I don't know 


\section{Appendix IV \\ Color Graphs for the Changes of the Lake}

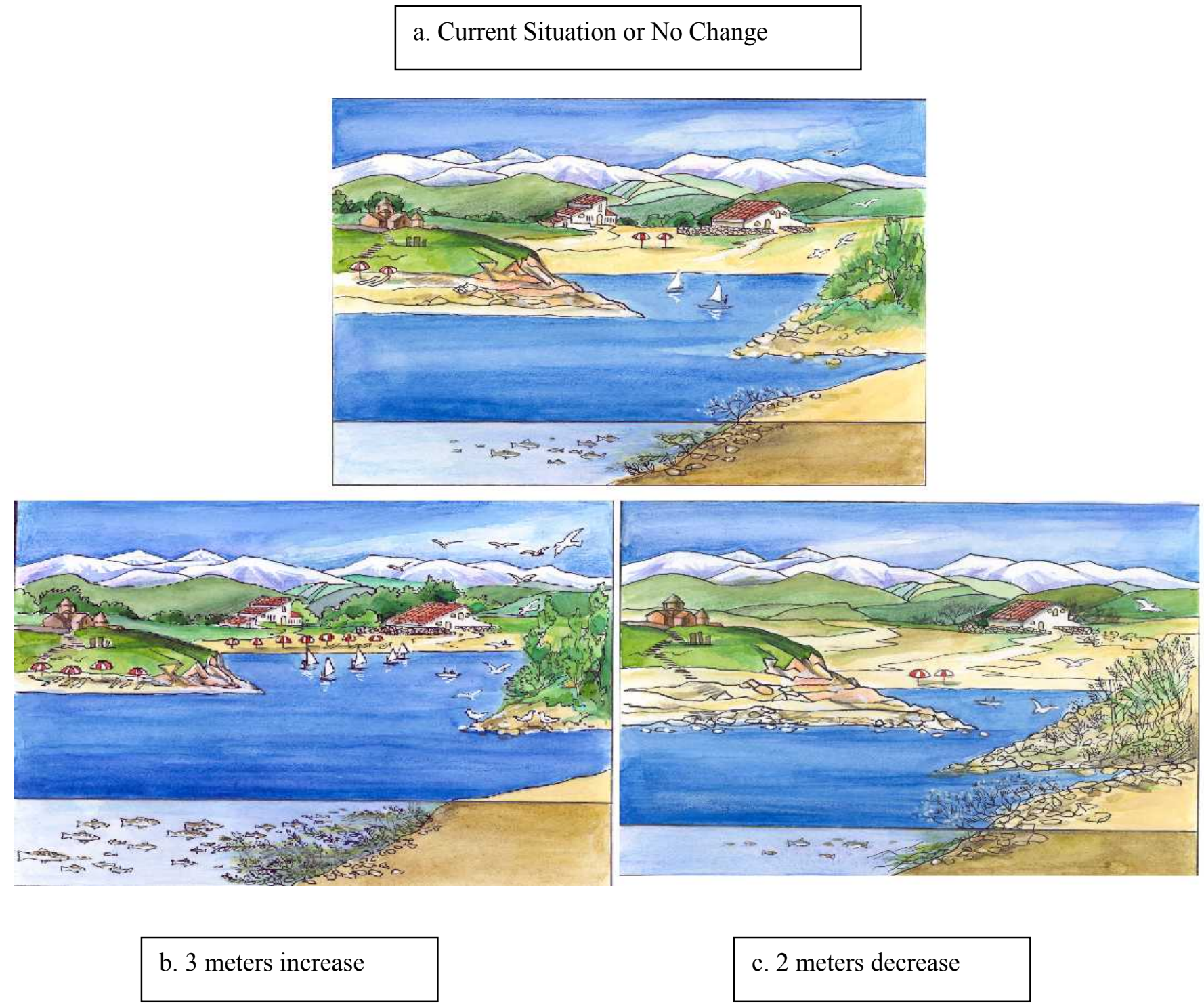




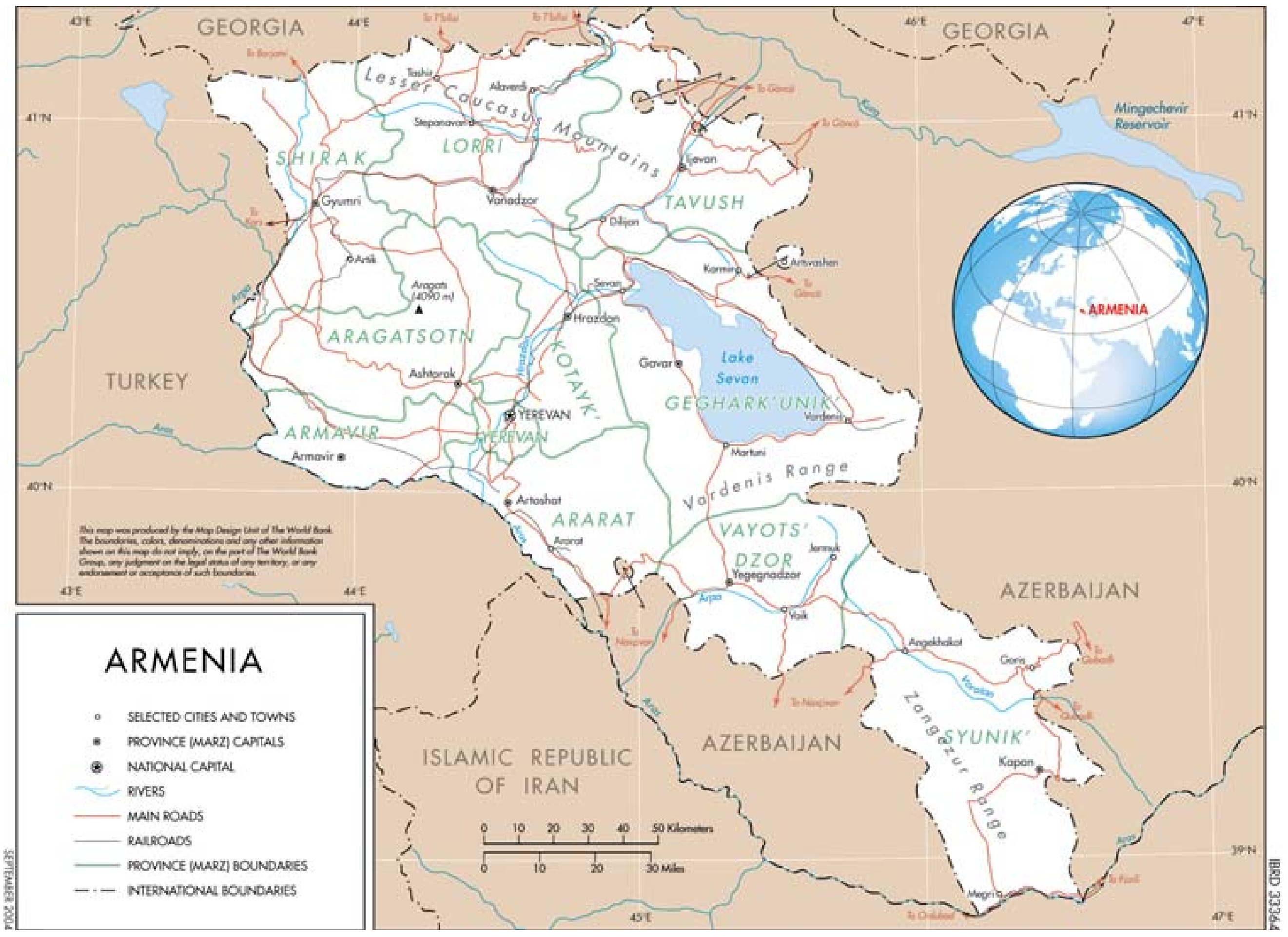

